\title{
Penyelesaian Sengketa Ekonomi Syariah Melalui Mediasi Pada Masa Pandemi di Pengadilan Agama Wilayah Yogyakarta ${ }^{1}$
}

\author{
Ani Yunita \\ Fakultas Hukum Universitas Muhammadiyah Yogyakarta Indonesia \\ Jln. Brawijaya, Tamantirto, Kasihan, Bantul, 55183 Yogyakarta Indonesia \\ aniyunita@umy.ac.id
}

Received: 28 Juli 2020; Accepted: 23 Maret 2021; Published: 2 Juni 2021

DOI: 10.20885 /iustum.vol28.iss2.art10

\begin{abstract}
Sharia economic dispute resolution through mediation has many advantages, but the percentage of success in the process of sharia economic dispute resolution through mediation at the Yogyakarta Regional Religious Court is still low. Furthermore, it was speculated that a pandemic condition gives influence to the mediation implementation optimally. The research was to examine the factors to the low success rate of sharia economic dispute resolution through mediation at the Yogyakarta Regional Religious Court. This research an empirical juridical study using primary data and secondary data with a statutory approach method. Data were analyzed escriptive-qualitative analysis. The results show that the settlement of sharia economic disputes through mediation at the Yogyakarta Regional Religious Court is still low due to several factors, among others, there are not many judge mediators who have mediator certificates and sharia economic certificates, the parties are not in good faith, there is no regulation regarding the presence of the parties through remote audio-visual intermediaries on the Covid-19 pandemic and the constraints of the fast handling process in the mediation process as already regulated in Supreme Court Regulation Number 1 of 2016 (PERMA No.1 Of 2016).
\end{abstract}

Key Words: Mediation; PERMA No. 1 of 2016; Religious Courts

Abstrak

Penyelesaian sengketa ekonomi syariah melalui mediasi memiliki banyak keunggulan, namun tingkat prosentase keberhasilan dalam proses penyelesaian sengketa ekonomi syariah melalui mediasi di Pengadilan Agama Wilayah Yogyakarta masih rendah. Apalagi ditengarai kondisi pandemi yang diduga juga memengaruhi optimalnya pelaksanaan mediasi. Tujuan penelitian ini untuk mengkaji faktor penyebab penyelesaian sengketa ekonomi syariah melalui mediasi di pada masa pandemi di Pengadilan Agama Wilayah Yogyakarta masih rendah. Penelitian ini merupakan penelitian yuridis empiris dengan menggunakan data primer dan data sekunder dengan metode pendekatan perundang-undangan. Data dianalisis menggunakan analisis deskriptif-kualitatif. Hasil penelitian menyimpulkan bahwa penyelesaian sengketa ekonomi syariah melalui mediasi pada masa pandemi di Pengadilan Agama Wilayah Yogyakarta masih rendah dikarenakan terdapat beberapa faktor antara lain belum banyak mediator hakim yang memiliki sertifikat mediator dan sertifikat ekonomi syariah, para pihak tidak beritikad baik, belum adanya pengaturan mengenai kehadiran para pihak melalui perantara audio visual jarak jauh atas alasan adanya pandemi Covid-19 dan kendala proses penanganan cepat dalam proses mediasi sebagaimana yang telah diatur dalam PERMA No 1 Tahun 2016.

Kata-kata Kunci: Mediasi; Pengadilan Agama; PERMA No 1 Tahun 2016

${ }^{1}$ Penelitian Dosen Pemula Dibiayai oleh Lembaga Penelitian, Publikasi dan Pengabdian Masyarakat Universitas Muhammadiyah Yogyakarta Tahun Anggaran 2019/2020. Penelitian ini dilaksanakan dibawah bimbingan Ibu Fadia Fitriyanti sebagai Coresponding Author. 


\section{Pendahuluan}

Pengadilan Agama merupakan salah satu lembaga peradilan yang menjalankan kekuasaan kehakiman yang fungsinya menyelesaikan perkara perdata tertentu di kalangan umat Islam di Indonesia. ${ }^{2}$ Pasal 24 UUD NRI 1945 menyatakan bahwa lingkungan Peradilan Agama merupakan salah satu pelaksana kekuasaan kehakiman di Indonesia, bersama lingkungan peradilan lainnya di bawah Mahkamah Agung. ${ }^{3}$ Pasca Undang-Undang Nomor 48 Tahun 2009 tentang Kekuasaan Kehakiman, tugas dan tanggung jawab pembinaan, organisasi, administrasi dan finansial semua lingkungan peradilan, termasuk Peradilan Agama dialihkan dari pemerintah kepada Mahkamah Agung. Dengan demikian, Peradilan Agama memiliki tugas dan kewenangan dalam penyelesaian sengketa ekonomi syariah.

Lahirnya Undang-Undang Nomor 3 Tahun 2006 tentang Peradilan Agama menambah kewenangan Peradilan Agama terkait dengan penyelesaian sengketa ekonomi syariah. Sebagaimana Pasal 49 Undang-Undang Nomor 3 Tahun 2006 yang menyatakan bahwa Peradilan Agama bertugas dan berwenang memeriksa, memutus, dan menyelesaikan perkara di tingkat pertama antara orang-orang yang beragama Islam di bidang perkawinan, kewarisan, wasiat, hibah, wakaf, zakat, infaq, shadaqah, dan ekonomi syari'ah. ${ }^{4}$

Penyelesaian sengketa ekonomi syariah secara litigasi terjadi sejak dikeluarkannya Putusan Mahkamah Konstitusi Nomor 93/PUU-X/2012 yang memberikan kewenangan mutlak kepada Peradilan Agama dalam proses penyelesaian sengketa ekonomi syariah secara litigasi di Pengadilan Agama. Para pihak dalam membuat akad ekonomi syariah dapat memilih penyelesaian perselisihan melalui jalur non litigasi dan litigasi. Penyelesaian yang dilakukan melalui jalur litigasi sejak Putusan Mahkamah Konstitusi Nomor 93/PUU-X/2012 tersebut diselesaikan melalui Pengadilan Agama sehingga Pengadilan Negeri tidak lagi berwenang menyelesaikan sengketa ekonomi syariah.

2 Yulkarnain Harahab, "Kesiapan Pengadilan Agama dalam Penyelesaian Sengketa Ekonomi Syariah", Jurnal Mimbar Hukum, Volume 20 No. 1, Februari, 2018, hlm. 112.

${ }^{3}$ Khoirun Nisa, "Putusan MK No. 93/Puu-X/2012 Menuju Kepastian Hukum Penyelesaian Sengketa Perbankan Syari'ah”, Jurnal Iqtishad, 4 (2), 2017, hlm. 32.

${ }^{4}$ Erie Haryanto, 2014, "Penyelesaian Sengketa Ekonomi Syariah Di Indonesia", Jurnal Iqtishadia, Vol. 1 No. 1 Juni, hlm. 51. 
Penyelesaian sengketa ekonomi syariah pada Pengadilan Agama pasca dikeluarkannya Peraturan Mahkamah Agung Nomor 14 Tahun 2016 tentang Tata Cara Penyelesaian Sengketa Ekonomi Syariah (selanjutnya ditulis PERMA SES) wajib mengikuti tata cara penyelesaian sebagaimana yang telah diatur dalam PERMA tersebut. PERMA SES mengatur secara detail mengenai ekonomi syariah, prinsip syariah, akad syariah dan tata cara penyelesaian perkara ekonomi syariah di Pengadilan Agama. Penyelesaian sengketa ekonomi syariah yang dimaksud termasuk proses penyelesaian melalui mediasi di Pengadilan Agama sebagaimana diatur dalam Pasal 10 Peraturan Mahkamah Agung Nomor 1 Tahun 2016 tentang Prosedur Mediasi di Pengadilan (selanjutnya ditulis PERMA MEDIASI).

Pasal 1 angka 1 PERMA MEDIASI menentukan bahwa mediasi adalah cara penyelesaian sengketa melalui proses perundingan untuk memeroleh kesepakatan para pihak dengan dibantu oleh mediator. ${ }^{5}$ Perdamaian dalam syariat Islam sangat dianjurkan, sebab dengan adanya perdamaian akan terhindar dari putusnya perpecahan silaturahmi (hubungan kasih sayang) sekaligus permusuhan di antara pihak-pihak yang bersengketa akan dapat diakhiri. ${ }^{6}$

Pada praktiknya, tingkat keberhasilan proses pelaksanaan mediasi di Pengadilan Agama Yogyakarta masih rendah dibandingkan dengan Pengadilan Agama Bantul. Hal ini terlihat pada pelaksanaan mediasi yang berhasil damai di Pengadilan Agama Yogyakarta pada kurun waktu 2016-2020 hanya 3 perkara yang berhasil damai dari 26 perkara yang diselesaikan,7 sedangkan perkara yang berhasil damai di Pengadilan Agama Bantul 2016-2020 berjumlah 10 dari 48 perkara ekonomi syariah yang diselesaikan. ${ }^{8}$ Hal ini menunjukkan masih rendahnya keberhasilan mediasi di Pengadilan Agama Yogyakarta.

Penelitian sebelumnya terkait mediasi pernah dilakukan oleh Darma Dian Saputra dkk dengan judul Implementasi Peraturan Mahkamah Agung Nomor 1 Tahun 2016 tentang Prosedur Mediasi di Pengadilan (Studi Pada Pengadilan Agama Tanjung Karang) membahas secara normatif tentang pelaksanaan PERMA

\footnotetext{
5 Nita Triana, "Urgensitas Mediator Dalam Penyelesaian Sengketa Ekonomi Syariah Di Pengadilan Agama Purbalingga", Law Reform, Volume 15, Nomor 2, 2019, hlm.240.

${ }^{6}$ Nur Fauzi, "Penyelesaian Sengketa Ekonomi Syariah Berbasih Sulh (Perdamaian) Untuk Mencapai Keadilan”, Jurnal Hukum Ekonomi Syariah, Volume I, Nomor 2, Oktober, 2018, hlm.214.

${ }^{7}$ Data yang diperoleh Peneliti dari Pengadilan Agama Yogyakarta pada 24 Juli 2020.

${ }^{8}$ Data yang diperoleh Peneliti dari Pengadilan Agama Bantul pada 14 Juli 2020.
} 
MEDIASI di Pengadilan Agama Tanjung Karang. ${ }^{9}$ Penelitian tersebut membahas pelaksanaan PERMA terhadap proses mediasi semua perkara di Pengadilan Agama Tanjung Karang. Sedangkan pada penelitian peneliti lebih fokus membahas penyelesaian sengketa ekonomi syariah melalui mediasi di Pengadilan Agama Wilayah Yogyakarta.

\section{Rumusan Masalah}

Berdasarkan uraian di atas maka rumusan masalah yang dikaji dalam penelitian ini ialah mengapa penyelesaian sengketa ekonomi syariah melalui mediasi pada masa pandemi di Pengadilan Agama Wilayah Yogyakarta masih rendah?

\section{Tujuan Penelitian}

Adapun tujuan penelitian ini adalah untuk mengetahui faktor penyebab penyelesaian sengketa ekonomi syariah melalui mediasi di Pengadilan Agama Wilayah Yogyakarta masih rendah.

\section{Metode Penelitian}

Jenis penelitian hukum yang digunakan adalah yuridis empiris. Penelitian ini menggunakan data primer dan data sekunder. Sumber data primer bersumber dari hasil wawancara dengan Hakim Pegadilan Agama Wilayah Yogyakarta yaitu Hakim Pengadilan Agama Yogyakarta, Bantul dan Sleman. Sumber data sekunder yang digunakan dalam penelitian ini terdiri dari bahan hukum primer, sekunder dan tersier. Bahan hukum primer terdiri dari Al Quran, Hadits, Fatwa Dewan Syariah Nasional Majelis Ulama Indonesia, Undang-Undang Nomor 48 Tahun 2009 tentang Kekuasaan Kehakiman, Undang-Undang Nomor 50 Tahun 2009 tentang Peradilan Agama, Undang-Undang Nomor 21 Tahun 2008 tentang Perbankan Syariah, Undang-Undang Nomor 30 Tahun 1999 tentang Arbitrase dan Alternatif Penyelesaian Sengketa, Peraturan Mahkamah Agung Nomor 14 Tahun 2016 tentang Tata Cara Penyelesaian Sengketa Ekonomi Syariah dan Perma Nomor 1 Tahun 2016 tentang Prosedur Mediasi di Pengadilan. Bahan hukum

9 Darma Dian Saputra dkk. Implementasi Peraturan Mahkamah Agung Nomor 1 Tahun 2016 tentang Prosedur Mediasi di Pengadilan (Studi Pada Pengadilan Agama Tanjung Karang), Pactum Law Journal, Vol 3.No. 3, 2019, hlm. 764 . 
sekunder antara lain beberapa buku-buku dan jurnal yang membahas tentang penyelesaian sengketa ekonomi syariah, mediasi dan Pengadilan Agama. Bahan hukum tersier yakni kamus hukum dan kamus bahasa Inggris.

Metode pendekatan yang digunakan dalam penelitian yuridis empiris ini ialah metode pendekatan perundang-undangan. Pendekatan perundangundangan yaitu pendekatan penelitian yang menggunakan peraturan perundangundangan maupun norma-norma hukum yang hidup di dalam masyarakat terutama yang berkaitan dengan penyelesaian sengketa ekonomi syariah melalui mediasi di Pengadilan Agama Wilayah Yogyakarta. ${ }^{10}$

Adapun teknik pengumpulan data untuk memperoleh sumber data primer ialah peneliti melakukan metode wawancara secara struktur dengan narasumber. Peneliti melakukan wawancara dengan menggunakan instrument penelitian berupa pedoman wawancara, alat bantu recorder dan kamera. Teknik pengumpulan data sekunder yang dilakukan peneliti ialah studi pustaka terhadap dokumen-dokumen dari pengadilan agama, peraturan perundangundangan, buku-buku dan jurnal-jurnal yang terkait dengan penyelesaian sengketa hukum ekonomi syariah. Studi dokumen atau pustaka merupakan suatu alat pengumpulan data yang dilakukan melalui data tertulis. ${ }^{11}$ Data sekunder sebagai data penelitian yang diambil dari bahan kepustakaan yang terdiri dari bahan hukum primer, bahan hukum sekunder dan bahan hukum tersier. Data yang diperoleh baik dari penelitian kepustakaan maupun dari penelitian lapangan akan diolah berdasarkan analisis deskriptif kualitatif.

\section{Hasil Penelitian dan Pembahasan}

Pertumbuhan dan perkembangan lembaga keuangan syariah di Indonesia pada 2020 menunjukkan peningkatan grafik. Menurut data statistik Perbankan Syariah yang dikeluarkan oleh Otoritas Jasa keuangan (OJK) pada Juli 2020 terdapat 14 Bank Umum Syariah (BUS), 20 Unit Usaha Syariah (UUS) dan 162

\footnotetext{
${ }^{10}$ Peter Mahmud Marzuki, Penelitian Hukum, Kencana, Jakarta, 2005, hlm. 93.

${ }^{11}$ Soerjono Soekanto, Pengantar Penelitian Hukum, Penerbit UI, Jakarta, 2006, hlm. 21.
} 
BPRS. ${ }^{12}$ Jumlah perusahaan asuransi syariah sebanyak 13 perusahaan asuransi syariah dan 49 Unit Usaha Syariah, serta 3 Lembaga Dana Pensiun Syariah.

Perbankan syariah merupakan salah satu lembaga yang melakukan kegiatan ekonomi syariah. Perbankan syariah di Indonesia sudah memiliki regulasi yang menjadi dasar hukum untuk pengakuan keberadaan lembaga perbankan syariah. Regulasi sangat penting untuk memberikan posisi yang kuat bagi lembaga perbankan syariah, memberikan kepastian hukum dan perlindungan hukum. ${ }^{13}$ Perbankan syariah sebagai lembaga intermediasi ekonomi dan keuangan, sehingga harus memenuhi konteks keadilan sosial, konsep distribusi yang adil, dan etika. ${ }^{14}$ Dengan adanya peningkatan industri keuangan syariah sebagai salah satu sektor terbesar dan cepat berkembang dalam perekonomian maka perselisihan dalam kegiatan ekonomi syariah pun akan meningkat. ${ }^{15}$

Pembiayaan adalah sumber pendapatan bank yang terbesar, namun sekaligus merupakan sumber risiko operasi bisnis yang terbesar. Pembiayaan bermasalah menjadi kategori macet dapat menjadi masalah bagi bank syariah, karena dengan adanya pembiayaan bermasalah bukan saja menurunkan pendapatan bagi bank syariah tetapi juga menurunkan jumlah dana operasional dan likuiditas keuangan bank syariah. ${ }^{16}$ Pengertian pembiayaan bermasalah adalah pembiayaan yang berada dalam klasifikasi diragukan dan macet (non performing loans). ${ }^{17}$ Dalam hal terdapat pembiayaan bermasalah, bank menjaga likuiditasnya dengan berusaha mengupayakan penyelesaian permasalahan yang dihadapinya.

Kehati-hatian di dalam mengelola proses secara syariah akan memberikan kepastian dan mencegah adanya permasalahan di dalam pelaksanaan akad

\footnotetext{
${ }^{12}$ https://keuangan.kontan.co.id/news/hingga-juli-2020-aset-keuangan-syariah-tembus-rp-163908 triliun diposting tanggal 21 September 2020.

13 Muhammad Arifin dan Bismar Nasution, "Dynamcic Studies Of Regulation Of Syariah Banking Indonesia", International Journal Humanities and Social Sciences.Vol.5 No.3, 2015, hlm. 238.

14 Muhammad Syafii Antonio, "Islamic Microfinance Initiatives To Enhance Small and Medium Interprises In Indonesia From Historical Overview to Contemporary Situation”, Journal Of Indonesian Islam, Vol. 5 No. 2 December 2011, hlm. 317.

15 Aida Maita, "Arbitration of Islamic Financial Disputes", Annual Survey of International \& Comparative Law, Volume 20 issue 1.2014, hlm. 36.

${ }^{16}$ Trisadini Prasastinah Usanti, "Pengelolaan Risiko Pembiayaan Di Bank Syariah", ADIL: Jurnal Hukum, Vol. 3 No. 2. hlm. 411.

${ }^{17}$ Sitti Shaleha Madjid, "Penanganan Pembiayaan Bermasalah Pada Bank Syariah", Jurnal Hukum Ekonomi Syariah, Vol. 2 No. 2. 2018, hlm. 98.
} 
sehingga para pihak dapat memenuhi prinsip syariah dan kepatuhan syariah. ${ }^{18}$ Hal ini sesuai dengan pendapat Shaykh Yusuf Talal De Lorenzo yang menyebutkan bahwa: "careful management of the shariah process will almost certainly help prevent this risk from becoming a problem". ${ }^{19}$ Berdasarkan asas Pacta Sunt Servanda maka akad para pihak yang dibuat secara sah mengikat para pihak sebagai undang-undang. Oleh karena itu, kepatuhan syariah juga dapat diukur dari adanya kepatuhan pada akad. ${ }^{20}$

Pelaksanaan akad di Lembaga Keuangan Syariah sering terjadi perselisihan pendapat baik dalam penafsiran maupun dalam implementasi isi akad. Persengketaan tersebut harus segera diantisipasi dengan cermat untuk menemukan solusi bagi pihak Lembaga Keuangan Syariah maupun nasabah. Jika para pihak Lembaga keuangan syariah dan pengguna jasa Lembaga keuangan syariah (nasabah) mengalami perselisihan dalam pelaksanaan akad maka dapat dilakukan penyelesaiannya melalui Pengadilan Agama.

Peradilan agama merupakan kekuasaan negara dalam memeriksa, mengadili, memutus, dan menyelesaikan perkara-perkara tertentu antar orangorang beragama Islam untuk menegakan keadilan sedangkan pengadilan agama ialah pengadilan di tingkat pertama pada lingkungan peradilan agama. Menurut Ramulyo, pengadilan agama merupakan tempat dimana dilakukan usaha untuk mencari keadilan dan kebenaran yang diridhai Tuhan Yang Maha Esa melalui majelis hakim. ${ }^{21}$

Pasal 49 Undang-Undang Nomor 50 Tahun 2009 sebagaimana perubahan kedua atas Undang-Undang Nomor 7 Tahun 1989 tentang Peradilan Agama dalam menyelesaikan sengketa ekonomi syariah berwenang memeriksa dan memutus sengketa tentang ekonomi Syariah. Tugas dan kewenangan pengadilan agama yaitu memeriksa, memutus dan menyelesaikan perkara tertentu bagi yang

\footnotetext{
${ }^{18}$ Michael JT Mc Millen, "Islamic Shariah Compliant Project Finance: Collateral Security and Financing Structure Case Studies”, Fordham International Law Journal, Vol 24.2000. hlm. 1188.

${ }^{19}$ Shaykh Yusuf Talal De Lorenzo, "Shari'ah Compliance Risk", Chicago Journal of International Law, Vol. 7, No. 2, 2007, hlm. 407.

${ }^{20}$ Husam Suleiman, "Crowdfunding and the Opportunity Presented in the American Islamic Financial Sphere", Journal of Islamic Banking and Finance, October-December 2016, hlm. 64.

${ }^{21}$ Jaenal Aripin, Peradilan Agama dalam Bingkai Reformasi Hukum di Indonesia, Prenadia Media Group, Jakarta, 2008, hlm. 254.
} 
beragama Islam dalam bidang perkawinan, waris, wasiat, hibah, wakaf, zakat, infaq, shadaqah dan ekonomi syariah.

Jika para pihak dalam kegiatan pembiayaan terjadi permasalahan maka penyelesaian sengketa dapat diajukan melalui mediasi di Pengadilan Agama. Penyelesaian sengketa melalui mediasi ialah proses pemecahan masalah di mana pihak luar yang tidak memihak (impartial) dan netral bekerja dengan pihak yang bersengketa untuk membantu memperoleh kesepakatan perjanjian yang memuaskan.

Menurut Kovact sebagaimana dikutip oleh Suyud Margono bahwa "mediasi berarti facilitatied negotiation, it process by which a neutral third party, the mediator, assist disputing parties in reaching a muttually satisfaction solution. ${ }^{22}$ Mediasi merupakan salah satu instrumen efektif penyelesaian sengketa non-litigasi yang memiliki banyak manfaat dan keuntungan. Manfaat dan keuntungan menggunakan jalur mediasi antara lain bahwa sengketa dapat diselesaikan dengan win-win solution, waktu yang digunakan tidak berkepanjangan, biaya lebih ringan, tetap terpelihara hubungan antara dua orang yang bersengketa dan terhindarkannya persoalan mereka dari publikasi yang berlebihan.

Mediasi adalah proses yang disepakati melalui negosiasi atau kesepakatan bagi para pihak yang bersengketa. Mediator sebagai pihak ketiga tidak memiliki wewenang untuk memutuskan atau memaksakan persetujuan. Para pihak selama proses mediasi harus didasarkan pada kesepakatan kedua belah pihak sehingga harus saling menghormati dan tidak ada paksaan untuk menerima atau menolak pendapat. Proses mediasi pada akhirnya adalah proses yang sama dengan negosiasi atau konsultasi. ${ }^{23}$

Pemahaman umum para pihak yang bersengketa terhadap mediasi masih belum maksimal dikarenakan para pihak hanya memahami esensi mediasi sekedar bertemu dengan pihak ketiga sebagai mediator. ${ }^{24}$ Para pihak yang bersengketa tidak melihat adanya manfaat lebih dari proses mediasi tersebut

\footnotetext{
${ }^{22}$ Suyud Margono, ADR \& Arbitrase (Proses Pelembagaan dan Aspek Hukum), Bogor Selatan, Ghalia Indonesia, 2004, hlm.28.

${ }^{23}$ Dewi Nurul Musjtari et all., "Reformulation Of mediation in Dispute Settlement on Islamic Banking", Humanities \& Social Science Reviews, Vol. 7 No. 4, 2019, hlm. 187.

${ }^{24}$ Muhammad Saifullah, "Efektivitas Mediasi Dalam Penyelesaian Perkara Perceraian di Pengadilan Agama Jawa Tengah”, Al Ahkam, Vol. 25, 2015, hlm. 195.
} 
sehingga pemahaman mengenai mediasi menjadi sangat penting. Seharusnya proses memberikan pemahaman terhadap manfaat penyelesaian perkara melalui mediasi (sosialisasi) harus dilakukan terlebih dahulu secara maksimal sehingga mendapatkan pemahaman dan pengetahuan akan pentingnya proses penyelesaian perkara melalui mediasi.

Diterapkannya PERMA MEDIASI di Pengadilan dapat menjadi salah satu upaya penyelesaian sengketa perdata terutama sengketa perbankan syariah. Pengadilan Agama dalam menyelesaikan suatu sengketa wajib terlebih dahulu mengupayakannya melalui mediasi. Upaya ini dilakukan agar para pihak yang bersengketa dapat mencapai kesepakatan untuk melakukan perdamaian. Upaya mediasi tentunya akan menguntungkan pula bagi para pihak yang bersengketa maupun Pengadilan Agama sendiri.

Keharusan melaksanakan mediasi pada perkara ekonomi syariah yang masuk ke pengadilan agama adalah salah satu ketentuan menarik dari Pasal 10 PERMA SES. Ketentuan tersebut menentukan bahwa hakim wajib terlebih dahulu mengupayakan perdamaian sebelum memeriksa perkara atas sengketa ekonomi syariah yang diajukan ke pengadilan. Ketentuan ini tidak boleh diabaikan serta perlu di perhatikan oleh berbagai pihak karena putusan pengadilan dapat batal demi hukum jika prosedur mediasi tidak dilakukan.

Penyelesaian sengketa ekonomi syariah melalui mediasi dilakukan berdasarkan PERMA MEDIASI, namun Pasal 2 PERMA MEDIASI juga memberlakukan ketentuan mengenai mediasi untuk proses berperkara di lingkungan peradilan umum maupun peradilan agama. Diketahui bahwa penyelesaian sengketa ekonomi syariah sejak dikeluarkan Putusan Mahkamah Konstitusi Nomor 93/PUU-X/2012 wajib diselesaikan melalui peradilan agama sehingga tidak lagi diselesaikan melalui peradilan umum termasuk Pengadilan Negeri.

Penulis melakukan penelitian di Pengadilan Agama Yogyakarta dan Pengadilan Agama Bantul. Penelitian di Pengadilan Agama Bantul pada Selasa, 14 Juli 2020. Penulis melakukan wawancara dengan Umar Faruq yang merupakan hakim Pengadilan Agama Bantul. Sedangkan di Pengadilan Agama Yogyakarta 
pada Selasa, 21 Juli 2020 dan Jumat 24 Juli 2020. Penulis melakukan wawancara dengan Ulil Uswah selaku hakim sekaligus mediator Pengadilan Agama Yogyakarta.

Dasar hukum penyelesaian sengketa ekonomi syariah yang digunakan di Pengadilan Agama pada umumnya dan Pengadilan Agama Wilayah Yogyakarta pada khususnya berlandaskan pada Pasal 130 HIR, Rv, RBG, Undang-Undang Nomor 50 Tahun 2009 tentang Perubahan Kedua atas Undang-Undang Nomor 7 Tahun 1989 tentang Peradilan Agama, PERMA SES, PERMA MEDIASI.

Rekapitulasi jumlah perkara ekonomi syariah di Pengadilan Agama Yogyakarta dalam kurun waktu 2016 s.d Juli 2020 dapat dilihat dalam tabel sebagai berikut:

Tabel 1.

Rekapitulasi Jumlah Perkara Ekonomi Syariah di Pengadilan Agama Yogyakarta pada 2016 s.d Juli 2020.

\begin{tabular}{ccccc}
\hline No & Tahun & Jumlah Perkara & $\begin{array}{c}\text { Perkara Berhasil } \\
\text { Mediasi/Damai }\end{array}$ & $\begin{array}{c}\text { Prosentase Keberhasilan } \\
\text { Mediasi (\%) }\end{array}$ \\
\hline 1 & 2016 & 4 & 1 & 25 \\
2 & 2017 & 8 & 1 & 12.5 \\
3 & 2018 & 3 & 0 & 0 \\
4 & 2019 & 8 & 1 & 12.5 \\
5 & 2020 & 3 & 0 & 0 \\
\multicolumn{2}{c}{ Jumlah } & $\mathbf{2 6}$ & $\mathbf{3}$ & $\mathbf{1 1 , 5 3}$ \\
\multicolumn{5}{l}{}
\end{tabular}

Berdasarkan tabel tersebut dapat dijelaskan bahwa jumlah perkara ekonomi syariah pada 2016 s.d 2020 berjumlah 26 perkara. Jumlah persentase keberhasilan damai yang tertinggi diperoleh pada 2016 yaitu 25\% sedangkan yang tidak ada keberhasilan dalam proses mediasi terjadi pada 2018 dan 2020. Dengan demikian, prosentase keberhasilan mediasi yang berhasil damai di Pengadilan Agama Yogyakarta dalam kurun waktu 5 tahun terakhir (2016 s.d Juli 2020) berjumlah 11,53\%. Data tersebut menunjukkan bahwa mediasi yang berhasil damai masih sangat minim. Dengan demikian, para pihak yang bersengketa belum menunjukkan iktikad baik dalam mengatasi perselisihan sebagaimana diatur dalam Pasal 7 PERMA MEDIASI. 
Rendahnya keberhasilan mediasi di Pengadilan Agama Yogyakarta tersebut menjadi persoalan hukum yang harus dikaji. Persoalan hukum tersebut antara lain belum semua mediator baik mediator hakim maupun mediator nonhakim mempunyai sertifikat kompetensi di bidang ekonomi syariah, para pihak tidak beritikad baik dan kendala penanganan cepat pada proses mediasi sebagaimana yang telah diatur dalam Peraturan Mahkamah Agung Nomor 1 Tahun 2016 tentang Prosedur Mediasi di Pengadilan.

Menurut Pasal 3 ayat (5) PERMA MEDIASI, tidak diperkenankan jika mediator hakim menyelesaikan proses mediasi sekaligus menjadi hakim pemeriksa perkara yang sama. Hal ini diperkuat oleh pernyataan Bapak Umar Faruq selaku hakim Pengadilan Agama Bantul. Hakim Pengadilan Agama Bantul berjumlah 6 orang termasuk Ketua. Hakim di Pengadilan Agama Bantul belum memiliki sertifikat mediator sehingga PA Bantul bekerjasama dengan Asosiasi Pengacara Syariah Indonesia, Universitas Islam Negeri Yogyakarta, Persatuan Advokat Indonesia Mantan Hakim Tinggi dan lain-lain.

Berbeda halnya dengan Pengadilan Agama Yogyakarta yang telah memiliki 7 orang hakim yang terdiri dari 1 orang Ketua, 1 orang Wakil Ketua dan 5 orang sebagai hakim fungsional. Mediator yang sudah memiliki sertifikat mediator (terdaftar dan memiliki ijin Praktek) di Pengadilan Agama Yogyakarta berjumlah 11 orang yaitu 1 orang hakim berasal dari Internal Pengadilan Agama Yogyakarta dan 10 orang mediator yang berasal dari luar (non hakim) Pengadilan Agama Yogyakarta. Pernyataan tersebut disampaikan oleh Ulil Uswah sebagai hakim yang telah memiliki sertifikat mediator dan Panitera di Pengadilan Agama Yogyakarta. Namun demikian, dikarenakan terdapat keterbatasan hakim yang memiliki sertifikat mediator maka hakim yang belum memiliki sertifikat mediator juga diijinkan menjadi mediator dalam proses mediasi.

Sebagian besar mediator di Pengadilan Agama Yogyakarta berasal dari luar PA Yogyakarta dikarenakan keterbatasan hakim yang memiliki sertifikat mediator. Mediator yang berasal dari luar PA Yogyakarta harus melakukan pendaftaran dan ditetapkan berdasarkan keputusan Ketua PA Yogyakarta. Jangka waktu menjadi mediator yang berasal dari luar PA di Pengadilan Agama 
Yogyakarta adalah 1 tahun. Mediator eksternal Pengadilan Agama Yogyakarta tersebut memiliki profesi yang beragam antara lain Pengacara, Badan Penasihat Pembinaan dan Pelestarian Perkawinan (BP4) dsb.

Pasal 13 ayat (1) PERMA MEDIASI menentukan bahwa mediator wajib memiliki sertifikat mediator. Akan tetapi, jika terdapat hakim yang belum memiliki sertifikat mediator dikarenakan keterbatasan jumlah mediator bersertifikat maka diperbolehkan menjadi mediator berdasarkan surat keputusan Ketua Pengadilan. ${ }^{25}$ Pada praktiknya ini terjadi di Pengadilan Agama Wilayah Yogyakarta yang masih mengalami keterbatasan jumlah mediator bersertifikat mediator. Itu pun belum semua mediator memiliki sertifikat mediator ekonomi syariah sehingga mediator belum cukup berpengalaman dalam melaksanakan proses mediasi terkait sengketa ekonomi syariah.

Sebagaimana di Pengadilan Agama Yogyakarta hanya ada 1 hakim yang bersertifikat mediator. Hal ini ditengarai PERMA No. 1 Tahun 2016 memang belum mengatur secara khusus mengenai mediator yang menyelesaikan mediasi perkara ekonomi syariah harus memiliki kompetensi di bidang hukum ekonomi syariah. Meski demikian, ketentuan mengenai hakim yang mengenai perkara ekonomi syariah harus memiliki sertifikat ekonomi syariah diatur dalam Pasal 2 PERMA No. 05 Tahun 2016 tentang Sertifikasi Hakim Ekonomi Syariah. Proses penyelesaian perkara ekonomi syariah yang baik, profesional dan optimal diperlukan mediator yang menangani telah tersertifikasi sebagai mediator ekonomi syariah.

Belum semua mediator baik mediator hakim maupun mediator nonhakim pada praktiknya mempunyai kompetensi di bidang ekonomi syariah. Menurut penulis, kompetensi di bidang ekonomi syariah ini sangat penting karena digunakan mediator sebagai bekal mediator dalam menyelesaikan sengketa ekonomi syariah. Mediator pada sengketa ekonomi syariah selain harus mengerti teknik mediasi juga harus ahli pada bidang yang disengketakan yaitu bidang ekonomi syariah. Hal ini akan semakin menguatkan perannya sebagai mediator pada sengketa ekonomi syariah yang ujungnya adalah keberhasilan mediasi.

25 Pasal 13 ayat (2) PERMA No. 1 Tahun 2016 tentang Prosedur Mediasi di Pengadilan, menentukan "Berdasarkan surat keputusan ketua Pengadilan, Hakim tidak bersertifikat dapat menjalankan fungsi Mediator dalam hal tidak ada atau terdapat keterbatasan jumlah Mediator bersertifikat". 
Tahapan proses mediasi dalam penyelesaian sengketa ekonomi Syariah di Pengadilan Agama Wilayah Yogyakarta berdasarkan Pasal 24 PERMA No 1 Tahun 2016 ialah sebagai berikut:

(1)Dalam waktu paling lama 5 (lima) hari terhitung sejak penetapan sebagaimana dimaksud dalam Pasal 20 ayat (5), Para Pihak dapat menyerahkan Resume Perkara kepada pihak lain dan Mediator.

(2)Proses mediasi berlangsung paling lama 30 (tiga puluh) hari terhitung sejak penetapan perintah melakukan Mediasi.

(3) Atas dasar kesepakatan para pihak, jangka waktu mediasi dapat diperpanjang paling lama 30 (tiga puluh) hari terhitung sejak berakhir jangka waktu sebagaimana dimaksud pada ayat (2).

(4)Mediator atas permintaan para pihak mengajukan permohonan perpanjangan jangka waktu mediasi sebagaimana dimaksud pada ayat (3) kepada Hakim Pemeriksa Perkara disertai dengan alasannya.

Apabila para pihak berhasil mencapai kesepakatan dalam proses mediasi maka harus mengikuti ketentuan sesuai dengan Pasal 27 dan 28 PERMA No 1

Tahun 2016 antara lain dijelaskan sebagai berikut:

Pasal 27

(1)Jika mediasi berhasil mencapai kesepakatan, para pihak dengan bantuan mediator wajib merumuskan kesepakatan secara tertulis dalam Kesepakatan Perdamaian yang ditandatangani oleh para pihak dan Mediator.

(2)Dalam membantu merumuskan Kesepakatan Perdamaian, mediator wajib memastikan Kesepakatan Perdamaian tidak memuat ketentuan yang: a. bertentangan dengan hukum, ketertiban umum, dan/atau kesusilaan; b. merugikan pihak ketiga; atau c. tidak dapat dilaksanakan.

(3)Dalam proses mediasi yang diwakili oleh kuasa hukum, penandatanganan Kesepakatan Perdamaian hanya dapat dilakukan apabila terdapat pernyataan para pihak secara tertulis yang memuat persetujuan atas kesepakatan yang dicapai.

(4)Para pihak melalui mediator dapat mengajukan Kesepakatan Perdamaian kepada Hakim Pemeriksa Perkara agar dikuatkan dalam Akta Perdamaian.

(5)Jika para pihak tidak menghendaki Kesepakatan Perdamaian dikuatkan dalam Akta Perdamaian, Kesepakatan Perdamaian wajib memuat pencabutan gugatan.

(6)Mediator wajib melaporkan secara tertulis keberhasilan mediasi kepada Hakim Pemeriksa Perkara dengan melampirkan Kesepakatan Perdamaian.

Pasal 28

(1) Setelah menerima Kesepakatan Perdamaian sebagaimana dimaksud dalam Pasal 27 ayat (6), Hakim Pemeriksa Perkara segera mempelajari dan menelitinya dalam waktu paling lama 2 (dua) hari.

(2)Dalam hal Kesepakatan Perdamaian diminta dikuatkan dalam Akta Perdamaian belum memenuhi ketentuan sebagaimana dimaksud dalam Pasal 27 ayat (2), Hakim Pemeriksa Perkara wajib mengembalikan Kesepakatan Perdamaian kepada Mediator dan Para Pihak disertai petunjuk tentang hal yang harus diperbaiki. 
(3) Setelah mengadakan pertemuan dengan Para Pihak, Mediator wajib mengajukan kembali Kesepakatan Perdamaian yang telah diperbaiki kepada Hakim Pemeriksa Perkara paling lama 7 (tujuh) hari terhitung sejak tanggal penerimaan petunjuk perbaikan sebagaimana dimaksud pada ayat (2).

(4)Paling lama 3 (tiga) hari setelah menerima Kesepakatan Perdamaian yang telah memenuhi ketentuan sebagaimana dimaksud dalam Pasal 27 ayat (2), Hakim Pemeriksa Perkara menerbitkan penetapan hari sidang untuk membacakan Akta Perdamaian.

(5) Kesepakatan Perdamaian yang dikuatkan dengan Akta Perdamaian tunduk pada ketentuan keterbukaan informasi di Pengadilan.

Berdasarkan ketentuan dalam Pasal 24 PERMA MEDIASI yang mengatur mengenai tahapan proses mediasi, khusus terkait penyerahan resume perkara dan jangka waktu mediasi di Pengadilan Agama Yogyakarta dan Bantul sudah mengikuti ketentuan PERMA tersebut. Apabila para pihak berhasil mencapai kesepakatan maka dituangkan dalam bentuk kesepakatan perdamaian yang dikuatkan dalam akta perdamaian. Selanjutnya, mediator wajib melaporkan secara tertulis keberhasilan mediasi kepada Hakim Pemeriksa Perkara dengan melampirkan Kesepakatan Perdamaian. Kesepakatan para pihak yang berhasil melakukan perdamaian dapat dikuatkan dengan akta perdamaian oleh hakim pemeriksa perkara sebagaimana diatur dalam Pasal 27 PERMA MEDIASI.

Jika para pihak tidak berhasil mencapai kesepakatan maka mediator wajib menyatakan mediasi tidak berhasil mencapai kesepakatan dan memberitahukannya secara tertulis kepada Hakim Pemeriksa Perkara. Ketidakberhasilan dalam proses mediasi terjadi dalam hal para pihak tidak menghasilkan kesepakatan sampai batas waktu paling lama 30 hari berikut perpanjangannya sebagaimana dimaksud dalam Pasal 24 ayat (2) dan ayat (3); atau para pihak dinyatakan tidak beriktikad baik sebagaimana dimaksud dalam Pasal 7 ayat (2) huruf d dan huruf e. Mediator wajib menyatakan mediasi tidak dapat dilaksanakan dan memberitahukannya secara tertulis kepada Hakim Pemeriksa Perkara. Setelah menerima pemberitahuan, maka Hakim Pemeriksa Perkara segera menerbitkan penetapan untuk melanjutkan pemeriksaan perkara sesuai dengan ketentuan hukum acara yang berlaku.

Proses mediasi di Pengadilan Agama Yogyakarta, jika para pihak tidak mencapai kesepakatan maka mediator menyatakan mediasi tidak berhasil 
mencapai kesepakatan dan memberitahukannya secara tertulis kepada Hakim Pemeriksa Perkara. Proses mediasi tidak berlangsung selama 30 hari tetapi bisa selama 2 minggu bahkan lebih dari 30 hari sebagaimana yang disampaikan oleh Hakim Pengadilan Agama Yogyakarta sesuai dengan permintaan para pihak.

Bagi mediator hakim, masalah keterbatasan waktu juga menjadi persoalan karena tersita untuk menyelesaikan tugas sebagai penyelesai perkara. Keterbatasan waktu mediator hakim terkait dengan jumlah perkara yang harus diselesaikan. Keterbatasan waktu yang dimiliki oleh mediator hakim ini menjadikan mediator hakim melakukan mediasi tidak berlangsung secara optimal sehingga penanganan tidak cepat.

Pasal 6 ayat (1) PERMA MEDIASI menentukan bahwa para pihak wajib menghadiri secara langsung pertemuan mediasi. Hal ini sebagaimana terjadi di Pengadilan Agama Bantul yang selama pandemi Covid-19 pelaksanaan mediasi masih mempertemukan para pihak secara langsung. Namun, ketentuan tersebut menjadi persoalan jika dikaitkan dengan adanya pandemi Covid-19, karena para pihak semestinya diperbolehkan hadir melalui komunikasi audio visual jarak jauh jika tidak bisa hadir secara langsung.

Namun, Pasal 6 ayat (3) PERMA MEDIASI memicu multitafsir. Penafsiran pertama, dikarenakan Pasal 6 ayat (2) PERMA MEDIASI melegitimasi kehadiran pihak melalui audio visual jarak jauh dianggap sebagai kehadiran langsung, maka kehadiran melalui audio visual tersebut pada dasarnya dapat dilakukan tanpa harus memenuhi alasan sah sebagaimana Pasal 6 ayat (4). Sedangkan penafsiran kedua, dikarenakan Pasal 6 ayat (3) PERMA MEDIASI menyatakan Ketidakhadiran Para Pihak secara langsung dalam proses Mediasi hanya dapat dilakukan berdasarkan alasan sah, maka seolah menyatakan ketidakhadiran di Pengadilan secara langsung (melainkan hadir melalui audio visual) dalam proses mediasi hanya dapat dilakukan berdasarkan alasan sah.

Sementara itu, menurut Pasal 6 ayat (4) PERMA MEDIASI, alasan sah ketidakhadiran secara langsung dibatasi hanya dalam 4 kondisi. (1) Kondisi kesehatan yang tidak memungkinkan hadir dalam pertemuan mediasi berdasarkan surat keterangan dokter; (2) dibawah pengampuan; (3) mempunyai 
tempat tinggal, kediaman atau kedudukan di luar negeri; atau (4) menjalankan tugas negara, tuntutan profesi atau pekerjaan yang tidak dapat ditinggalkan. Namun demikian, alasan adanya pandemi Covid-19 sebagai keadaan yang memaksa/darurat sehingga para pihak diperbolehkan tidak dapat hadir secara langsung ke Pengadilan, melainkan melalui audio visual belum diatur dalam ketentuan Pasal 6 ayat (4) PERMA MEDIASI.

Kendala lain dalam proses penyelesaian mediasi di Pengadilan Agama Yogyakarta ialah mengenai ketidakhadiran salah satu pihak dalam mediasi. Sebagaimana dalam Pasal 7 ayat (1) PERMA MEDIASI dinyatakan bahwa para pihak wajib menempuh mediasi dengan iktikad baik. Proses mediasi yang dilakukan tanpa hadirnya salah satu para pihak yang telah dipanggil secara patut maka menjadi kendala proses mediasi untuk dilaksanakan. Jika para pihak tidak hadir maka dinyatakan tidak beritikad baik oleh mediator sebagaimana tertuang dalam Pasal 7 ayat (2) PERMA MEDIASI sehingga hal ini semakin memperkecil kemungkinan keberhasilan mediasi.

\section{Penutup}

Berdasarkan hasil penelitian dan pembahasan yang telah diuraikan diperoleh kesimpulan bahwa penyelesaian mediasi di Pengadilan Agama Wilayah Yogyakarta masih belum optimal dikarenakan terdapat beberapa kendala antara lain belum banyak mediator hakim yang memiliki sertifikat mediator dan sertifikat ekonomi syariah, para pihak tidak beritikad baik, belum adanya pengaturan mengenai kehadiran para pihak melalui perantara audio visual jarak jauh atas alasan adanya pandemi Covid-19, dan kendala proses penanganan cepat dalam proses mediasi di Pengadilan Agama Wilayah Yogyakarta sebagaimana yang telah diatur dalam PERMA MEDIASI.

Penulis merekomendasikan kepada Mahkamah Agung untuk segera melakukan upaya meningkatkan pengetahuan dan kemampuan hakim dalam menangani sengketa ekonomi syariah, mengusulkan kepada Mahkamah Agung untuk menambah jumlah hakim agar sesuai dengan jumlah ideal hakim yang harus ada pada pengadilan agama sehingga proses penanganan perkara bisa berjalan cepat. Selain itu, perlu melakukan rekonstruksi PERMA MEDIASI terkait 
dengan penyelesaian mediasi di Pengadilan Agama yang mengatur khusus terkait mediasi pada sengketa ekonomi syariah, serta mengakomodasi pengaturan kehadiran para pihak melalui perantara audio visual jarak jauh atas alasan adanya pandemi Covid-19.

\section{Daftar Pustaka}

\section{Buku}

Aripin, Jaenal, Peradilan Agama dalam Bingkai Reformasi Hukum di Indonesia, Prenadia Media Group, Jakarta, 2008.

Margono, Suyud, "ADREArbitrase (Proses Pelembagaan dan Aspek Hukum)", Ghalia Indonesia, Bogor Selatan, 2004.

Marzuki, Peter Mahmud, Penelitian Hukum, Kencana, Jakarta, 2005.

Soekanto, Soerjono, Pengantar Penelitian Hukum, Penerbit UI, Jakarta, 2006.

\section{Jurnal}

Aida Maita, "Arbitration of Islamic Financial Disputes", Annual Survey of International \& Comparative Law, Vol. 20, issue 1, 2014.

Dewi Nurul Musjtari, et all., "Reformulation Of mediation in Dispute Settlement on Islamic Banking", Humanities \& Social Science Reviews, Vol. 7, No. 4, 2019.

Darma Dian Saputra, dkk., “Implementasi Peraturan Mahkamah Agung Nomor 1 Tahun 2016 tentang Prosedur Mediasi Di Pengadilan (Studi Pada Pengadilan Agama Tanjung Karang)", Pactum Law Journal, Vol 3. No. 3. 2019.

Erie Haryanto, "Penyelesaian Sengketa Ekonomi Syariah Di Indonesia", Jurnal Iqtishadia, Vol. 1 No. 1, Juni, 2014.

Husam Suleiman, "Crowdfunding and the Opportunity Presented in the American Islamic Financial Sphere", Journal of Islamic Banking and Finance, October-December, 2016.

Khoirun Nisa, "Putusan Mk No. 93/Puu-X/2012 Menuju Kepastian Hukum Penyelesaian Sengketa Perbankan Syari'ah", Jurnal Iqtishad, Vol. 4 (2), 2017.

Michael JT Mc Millen, "Islamic Shariah Compliant Project Finance: Collateral Security and Financing Structure Case Studies", Fordham International Law Journal, Vol. 24, 2000.

Muhammad Arifin dan Bismar Nasution, "Dynamcic Studies Of Regulation Of Syariah Banking Indonesia", International Journal Humanities and Social Sciences, Vol. 5 No. 3, 2015.

Muhammad Saifullah, "Efektivitas Mediasi Dalam Penyelesaian Perkara Perceraian Di Pengadilan Agama Jawa Tengah", Al Ahkam, Vol. 25, 2015. 
Muhammad Syafii Antonio, "Islamic Microfinance Initiatives To Enhance Small and Medium Interprises In Indonesia From Historical Overview to Contemporary Situation", Journal Of Indonesian Islam, Vol. 5 No. 2, December, 2011.

Nita Triana, "Urgensitas Mediator Dalam Penyelesaian Sengketa Ekonomi Syariah Di Pengadilan Agama Purbalingga", Law Reform, Vol. 15, No. 2, 2019.

Nur Fauzi, “Penyelesaian Sengketa Ekonomi Syariah Berbasih Sulh (Perdamaian) Untuk Mencapai Keadilan", Jurnal Hukum Ekonomi Syariah, Vol. I, Nomor 2, Oktober, 2018.

Sitti Shaleha Madjid, "Penanganan Pembiayaan Bermasalah Pada Bank Syariah", Jurnal Hukum Ekonomi Syariah, Vol. 2 No. 2, 2018.

Shaykh Yusuf Talal De Lorenzo, "Shari'ah Compliance Risk", Chicago Joirnal of International Law, Vol. 7, No. 2, 2007.

Trisadini Prasastinah Usanti, "Pengelolaan Risiko Pembiayaan Di Bank Syariah", ADIL: Jurnal Huku, Vol. 3 No. 2.

Yulkarnain Harahab, "Kesiapan Pengadilan Agama dalam Penyelesaian Sengketa Ekonomi Syariah”, Jurnal Mimbar Hukum, Volume 20 No. 1, Februari, 2018.

\section{Internet}

https: / / keuangan.kontan.co.id/news/hingga-juli-2020-aset-keuangan-syariahtembus-rp-163908 triliun diposting tanggal 21 September 2020.

\section{Peraturan Perundang-undangan}

Undang-Undang Nomor 50 Tahun 2009 tentang Perubahan Kedua atas UndangUndang Nomor 7 Tahun 1989 tentang Peradilan Agama, Tambahan Lembaran Negara RI Nomor 159.

Undang-Undang Nomor 48 Tahun 2009 tentang Kekuasaan Kehakiman, Tambahan Lembaran Negara RI Nomor 5076.

Undang-Undang Nomor 21 Tahun 2008 tentang Perbankan Syariah, Tambahan Lembaran Negara RI Nomor 94.

Peraturan Mahkamah Agung Nomor 14 Tahun 2016 tentang Tata Cara Penyelesaian Sengketa Ekonomi Syariah, Berita Negara RI Nomor 2059.

Peraturan Mahkamah Agung Nomor 1 Tahun 2016 tentang Prosedur Mediasi Di Pengadilan, Berita Negara RI Nomor 175.

Peraturan Mahkamah Agung Nomor 5 Tahun 2016 tentang Sertifikasi Hakim Ekonomi Syariah, Berita Negara RI Nomor 597.

\section{Putusan Pengadilan}

Putusan Mahkamah Konstitusi Nomor 93/PUU-X/2012 tentang Pengujian Undang-Undang atas Undang-Undang Nomor 21 Tahun 2008 tentang Perbankan Syariah. 